https://doi.org/10.48009/2_iis_2008_243-251

\title{
ASSESSING STUDENTS' PERCEPTIONS OF PROJECT MANAGEMENT BEFORE AND AFTER COMPLETION OF A PROJECT MANGAMENT COURSE
}

\author{
Thomas Case, Georgia Southern University, tcase@georgiasouthern.edu \\ Manouchehr Tabatabaei, Georgia Southern University, mtabatab@georgiasouthern.edu
}

\begin{abstract}
Project management (PM) is increasingly important in both corporate and academic venues. Its importance has been recognized for several decades, but has recently received more attention because effective project managers are in high demand and short supply. University computing and engineering programs are being pressured by employers to better prepare students for project management positions and this has often resulted in student exposure to project management concepts in one or more courses. More graduate and undergraduate courses in project management are also being offered at colleges and universities because Information Systems (IS) curricula models specify exposure to project management. The present investigation focuses on how exposure to a project management course affects student perceptions of the overall importance of project management and the subject areas that project management subsumes. Student perceptions were assessed by surveying undergraduate students at a regional institution in the southeast U.S. at the beginning and end of a Project Management course. The results suggest that students exit the project management courses thinking that the subject matter is important and will contribute to career success. The results also suggest that the project management course has an especially strong impact on the perceptions of female students and that the course and that it significantly increases the perceived importance of multiple "hard" and "soft" course-related topics.
\end{abstract}

Keywords: Project Management (PM), Effective Project Managers, PM Course Assessment, PM Knowledge Areas, Gender Differences

\section{INTRODUCTION}

Project Management (PM) is an important component of undergraduate and graduate programs in computing curricula including those for Information Systems (IS) and Information Technology (IT). PM has been identified as an integral part of the IS curriculum in the IS 2002
Model Curriculum (Gorgone, J. et. al. 2002) and it is expected to continue to be explicitly recommended in the next IS model curriculum that is currently in the last stages of being finalized. In the IS 2002 Model Curriculum, PM is suggested as a capstone course to integrate concepts that students are exposed to in other IS courses, especially those in application development and systems analysis and design courses. This model curriculum recommends requiring students to engage in and complete a major system development project as part of the course. In addition, ABET accreditation criteria include the ability to assist in the creation of an effective project plan as one of the required skills for graduates from accredited Information Technology (IT) and IS degree programs (ABET 2004).

In response to the inclusion of PM in IS 2002 Model Curriculum recommendations and ABET accreditation criteria, numerous IS and IT programs now enable their students to take one or more PM courses. Many PM courses are project-based that require the completion of realistic individual and group projects and most are designed to help students develop PM skills. Such skills contribute to decreasing problems associated with IT project failures, such as the inability to meet schedule deadlines or to stay within budget limits. With nearly $\$ 1$ trillion spent annually on IT projects in the US, the need for individuals with PM skills is unlikely to decrease (Capell, 2001; Reif \& Mitri, 2005b).

While hundreds of research articles have been published that document the high value that corporations and educators place on project management, the extent to which project management is perceived as being important by students has been largely ignored. Numerous articles have been published on the instructional approaches used in university-level PM courses (e.g., Reif \& Mitri, 2005a), and the majority of these have focused on the use of projects in PM courses. From these studies, we have learned much about the impact of specific pedagogical techniques (such as project assignments) on student learning outcomes, but we have learned little about how exposure to PM concepts in project management courses affect 
student perceptions of the skill sets that project managers should possess.

Requisite project manager competencies and skill sets have been of interest to both corporate researchers/consultants (e.g. Udo \& Koppensteiner, 2004) and academicians (e.g., Brewer, 2005). Corporate researchers/consultants are often interested in identifying a trainable set of competencies; however, the breadth of the skill set may be quite large. For example, Brill et al (2006) identified 78 trainable competencies in the first round of their Delphi study and the corporate experts participating in this study identified more than 120 distinct characteristics of effective project managers. The set of trainable competencies was reduced to 42 in the second round of their Delphi study. Brewer (2005) also provides evidence that the skill set that characterizes effective project managers is broad. As noted by Bourne \& Walker (2004), effective project managers are required to possess both "hard" technical skills and relationship management skills to get the best out of the members of their project teams; they also provide evidence that effective project managers must be able to manage the expectations of project stakeholders, especially those with considerable political power within their organizations.

The investigation described below shares Brewer's (2005) contention that educators at colleges and universities must first know the skills and competencies possessed by effective project managers before they can begin preparing their students for project manager careers. It seeks to build on his work and that of Brill et al (2006) and Wu (2005) by examining student perceptions of the skills/knowledge that effective project managers should possess at both the beginning and end of their project management course. The pre-post survey method used in our investigation also provides insight into how a project management course can contribute to changing student or trainee views about the relative importance of particular skills and expertise required for effective project management practices. The current investigation also provides insight into student perceptions of the extent to which project management knowledge is important to IT career success.

\section{Purpose}

The primary purpose of this investigation is to gain insights into student perceptions of the importance of project management and PM-relevant knowledge dimensions before taking a project management course and to assess how these perceptions change as the result of being exposed to PM concepts across the semester. Secondary objectives of this investigation were to assess whether initial perceptions and changes in perceptions are influenced by major, gender, and extent of business knowledge. This investigation was also carried out to provide course assessment data for both ABET (which accredits the university's IT degree program) and the AACSB (which accredits the university's IS and other business degree programs).

\section{METHODOLOGY}

Paper-based survey instruments were used in this investigation. This survey items were derived from the skills and competencies of effective project managers identified by the PMI and PMBOK (2000) and those identified by previous researchers (Bigelow, 2000; Baker, Tjosvold, and Andrews, 1988; Bourne and Walker, 2004; Brewer, 2005; Brill, Bishop, and Walker, 2006; Milosevic, 2003; Udo and Koppensteiner, 2004; White, 2002; and Wu, 2005).

The most extensive survey instrument used in this investigation was administered at both the beginning and at the end of the semester. It included two major sections: (1) demographics, and (2) rating the importance of 96 different knowledge dimensions to the practice of project management. A seven-point scale was used to assess student perceptions of the knowledge dimensions:

- $0=\mathrm{I}$ know nothing about this knowledge area

- 1 = I know about this area, but don't know how it relates to $\mathrm{PM}$

- 2 = very little importance

- 3 = little importance

- 4 = some importance

- 5 = very important

- 6 = extremely important.

A second survey instrument was administered that focused on the overall importance of project management knowledge and courses. A five-point Likert scale from strongly agree (5) to strongly disagree (1) was used for each item on the second survey.

\section{Participants}


The participants of this study were undergraduate students enrolled in the Project Management course at a regional university in the Southeast U.S. The survey was completed by a total of 72 students during the first week of their Project Management course. Thirty-eight students were enrolled in two sections of Project Management taught by the same instructor during Fall Semester 2006; the rest (35) were enrolled in two sections of the same instructor's Project Management during Spring Semester 2007.

The survey was also completed during the final week of the semester. During Fall Semester 2006, seven students who completed the survey at the beginning of the course did not complete the survey at the end of the semester. Course withdrawals and lack of a unique identifier made it impossible to match end-ofsemester with start-of-semester survey responses for Fall Semester 2006 students with any degree of certainty. A unique identifier was collected for both survey administrations during Spring Semester 2007 to enable better tracking of patterns of changes in perceptions from the beginning to the end of the semester.

\section{RESULTS}

Fifty-eight of the students were male and 14 were female. The vast majority of the students (80.6\%) were $20-22$ years of age and $95.9 \%$ were less than 26 years old. Most of the students were classified as seniors (84.9\%) and the rest were juniors (15.1\%). Fifty-nine of the students were IT majors (80.8\%) and the rest were IS majors. Twenty-three of the IT majors (31.5\% of the total number of respondents) were pursuing second-disciplines in business.

Table 1 summarizes the 30 knowledge dimensions perceived by students to be most important to the practice of Project Management at the end of the course. It also summarizes the rank of the mean for this same dimension at the beginning of the course. Table 1 suggests that the PM course did not result in major changes in student perceptions of the most important PM knowledge areas. Although there was some shifting in the ranks of the means, 23 of the knowledge dimensions included in the top 30 at the beginning of the course remained in the top thirty at the end of the course. Only one knowledge dimension, Change Management, rose from close to the bottom of the ranked means at the beginning of the course to the top 10 of the ranked means at the end of the course. Ethics also demonstrated a rise in importance from course start to course end, but the magnitude of change for this knowledge dimension was much less than that observed for Change Management.

Table 1: The 30 Most Important Knowledge Areas at Course End

\begin{tabular}{|c|c|c|c|c|}
\hline Dimension & $\begin{array}{c}\text { End } \\
\text { Mean } \\
(n=65)\end{array}$ & $\begin{array}{l}\text { End } \\
\text { Rank }\end{array}$ & $\begin{array}{c}\text { Start } \\
\text { Mean } \\
(\mathrm{n}=72)\end{array}$ & $\begin{array}{l}\text { Start } \\
\text { Rank }\end{array}$ \\
\hline Leadership & 5.78 & 1 & 5.66 & 4 \\
\hline Organizing & 5.65 & 2 & 5.71 & 1 \\
\hline $\begin{array}{l}\text { Time } \\
\text { Management }\end{array}$ & 5.63 & 3 & 5.59 & 5 \\
\hline Planning & 5.62 & 4 & 5.70 & 2 \\
\hline Motivation & 5.58 & 5 & 5.58 & 6 \\
\hline $\begin{array}{l}\text { Management } \\
\text { Principles }\end{array}$ & 5.58 & 6 & 5.47 & 14 \\
\hline Scheduling & 5.56 & 7 & 5.44 & 17 \\
\hline $\begin{array}{l}\text { Oral } \\
\text { Commun. }\end{array}$ & 5.55 & 8 & 5.56 & 9 \\
\hline $\begin{array}{l}\text { Decision } \\
\text { Making }\end{array}$ & 5.54 & 9 & 5.67 & 3 \\
\hline $\begin{array}{l}\text { Change } \\
\text { Management }\end{array}$ & 5.51 & 10 & 3.58 & 91 \\
\hline $\begin{array}{l}\text { Assigning } \\
\text { Priorities }\end{array}$ & 5.49 & 11 & 5.58 & 7 \\
\hline $\begin{array}{l}\text { Problem } \\
\text { Solving }\end{array}$ & 5.45 & 12 & 5.55 & 10 \\
\hline $\begin{array}{l}\text { Conflict } \\
\text { Resolution }\end{array}$ & 5.43 & 13 & 5.34 & 24 \\
\hline $\begin{array}{l}\text { Making } \\
\text { Presentations }\end{array}$ & 5.43 & 14 & 5.48 & 13 \\
\hline Controlling & 5.43 & 15 & 5.47 & 15 \\
\hline $\begin{array}{l}\text { Written } \\
\text { Commun. }\end{array}$ & 5.42 & 16 & 5.25 & 31 \\
\hline Negotiation & 5.40 & 17 & 5.15 & 37 \\
\hline PM Software & 5.38 & 18 & 5.42 & 18 \\
\hline $\begin{array}{l}\text { Assigning } \\
\text { Respons. }\end{array}$ & 5.38 & 19 & 5.34 & 23 \\
\hline $\begin{array}{l}\text { Running } \\
\text { Meetings }\end{array}$ & 5.35 & 20 & 5.42 & 19 \\
\hline $\begin{array}{l}\text { Business } \\
\text { Processes }\end{array}$ & 5.34 & 21 & 5.42 & 20 \\
\hline Team Player & 5.34 & 22 & 5.38 & 22 \\
\hline $\begin{array}{l}\text { Maintaining } \\
\text { Team } \\
\text { Synergy }\end{array}$ & 5.32 & 23 & 5.19 & 34 \\
\hline $\begin{array}{l}\text { Effective } \\
\text { Listening }\end{array}$ & 5.32 & 24 & 5.45 & 16 \\
\hline Ethics & 5.31 & 25 & 4.92 & 52 \\
\hline Integrating & 5.31 & 26 & 5.14 & 38 \\
\hline Budgeting & 5.31 & 27 & 5.26 & 29 \\
\hline $\begin{array}{l}\text { Team } \\
\text { Building }\end{array}$ & 5.29 & 28 & 5.56 & 8 \\
\hline
\end{tabular}




\begin{tabular}{|l|c|c|c|c|}
\hline $\begin{array}{l}\text { Evaluating } \\
\text { Decision } \\
\text { Alternative }\end{array}$ & 5.29 & 29 & 5.48 & 12 \\
\hline $\begin{array}{l}\text { General } \\
\text { Business } \\
\text { Concepts }\end{array}$ & 5.29 & 30 & 5.19 & 33 \\
\hline
\end{tabular}

Multiple “clusters" of important PM knowledge areas/skills may be observed in student survey responses. These include:

- Leading - (Leadership, Motivation, Oral Communication, Making Presentations, Integrating, Effective Listening, and Ethics)

- Communication - (Oral Communication, Negotiation, Written Communication, Making Presentations, and Effective Listening)

- Time \& Budget Management - (Time Management, Scheduling, Assigning Priorities, Budgeting, and PM Software)

- General Management - (Planning, Organizing, Controlling, and Management Principles)

- Group Management - (Team Building, Maintaining Team Synergy, and Assigning Responsibilities)

- Decision Making - (Decision Making, Problem Solving, and Evaluating Decision Alternatives)

- Business Knowledge - (General Business Concepts, Business Processes

- Change \& Conflict Management - (Change Management, and Conflict Management)

Because students perceived most of the items in each cluster as being important both at the beginning and end of the course, they provide insight into the key characteristics included in student profiles of effective project managers.

Table 2 indicates that the PM course did not cause major alterations in student perceptions of the knowledge dimensions they considered to be less important to the practice of project management. The 20 knowledge areas clumped at the bottom of the ranked means at the end of the course tended to be the same ones perceived as being less important at the beginning of the course.

The "clusters" of less important PM knowledge areas/skills observed in student survey responses may be summarized as follows:
- $\quad$ Software - (Application Software, Operating Systems, System Support Software, and Database Management Systems)

- Software Development -- ( Software Engineering, Programming, CASE Tools, Data Normalization, and Mathematics)

- Hardware - (IT Hardware and Networking Technologies)

- Social Science - (Psychology, Sociology, Economics, and Ergonomics)

- Business Disciplines -- (Accounting, Finance, Marketing, and Sales)

Table 2: The 20 Knowledge Areas Perceived as Least Important at Course End

\begin{tabular}{|l|c|c|c|c|}
\hline Dimension & $\begin{array}{c}\text { End of } \\
\text { Course } \\
\text { Mean }\end{array}$ & $\begin{array}{c}\text { End of } \\
\text { Course } \\
\text { Rank }\end{array}$ & $\begin{array}{c}\text { Start } \\
\text { of } \\
\text { Course } \\
\text { Mean }\end{array}$ & $\begin{array}{c}\text { Start } \\
\text { of } \\
\text { Course } \\
\text { Rank }\end{array}$ \\
\hline $\begin{array}{l}\text { Application } \\
\text { Software }\end{array}$ & 4.69 & 77 & 4.59 & 70 \\
\hline $\begin{array}{l}\text { Operating } \\
\text { Systems }\end{array}$ & 4.68 & 78 & 4.60 & 69 \\
\hline $\begin{array}{l}\text { Database } \\
\text { Systems }\end{array}$ & 4.64 & 79 & 4.81 & 61 \\
\hline $\begin{array}{l}\text { Current } \\
\text { Events }\end{array}$ & 4.61 & 80 & 4.55 & 72 \\
\hline IT Hardware & 4.61 & 81 & 4.58 & 71 \\
\hline $\begin{array}{l}\text { Network } \\
\text { Technologies }\end{array}$ & 4.55 & 82 & 4.40 & 77 \\
\hline $\begin{array}{l}\text { System } \\
\text { Support } \\
\text { Software }\end{array}$ & 4.54 & 83 & 4.53 & 73 \\
\hline Mathematics & 4.51 & 84 & 4.11 & 84 \\
\hline Psychology & 4.48 & 85 & 3.81 & 89 \\
\hline Finance & 4.45 & 86 & 4.49 & 74 \\
\hline CASE Tools & 4.42 & 87 & 3.73 & 90 \\
\hline Sociology & 4.38 & 88 & 3.83 & 88 \\
\hline $\begin{array}{l}\text { Data } \\
\text { Normalization }\end{array}$ & 4.38 & 89 & 4.68 & 66 \\
\hline Accounting & 4.31 & 90 & 4.26 & 80 \\
\hline Economics & 4.30 & 91 & 4.34 & 78 \\
\hline $\begin{array}{l}\text { Software } \\
\text { Engineering }\end{array}$ & 4.28 & 92 & 4.05 & 85 \\
\hline Programming & 4.20 & 93 & 4.32 & 79 \\
\hline Marketing & 4.17 & 94 & 4.15 & 82 \\
\hline Sales & 4.02 & 95 & 4.00 & 86 \\
\hline Ergonomics & 3.98 & 96 & 3.28 & 93 \\
\hline
\end{tabular}

When the previously identified rating scale values are considered, it is apparent that students rarely considered these "less important" knowledge areas and clusters as "unimportant"; they are best 
interpreted as being of lesser importance to the practice of project management than the knowledge areas summarized in Table 1.

\section{Demographic Factors and End of Course Knowledge Dimension Importance}

One-way ANOVAs were performed to assess whether semester, gender, major, or second discipline were systematically related to the perceived importance of the knowledge dimensions at the end of the course. Relative to Fall Semester 2006 students, students taking PM during Spring Semester 2007 provided perceived importance ratings that were significantly higher ( $\mathrm{p}<.05$ or better) for Forecasting, Organization Culture, Conflict Resolution, Outsourcing, and Procurement.

Significant differences $(\mathrm{p}<.05)$ between the end of course perceptions of male and female students were observed for only two items: Human Resource Management (males $>$ females) and Function Point analysis (males < females). Marginally significant differences $(p<.10)$ between males and females were observed on seven other items: Organization Politics, Budgeting, ROI Calculation, PERT, Systems Design, Logical Thinking, and Economics.

No significant differences were observed in the endof-course perceptions of IT and Information Systems majors. A marginally significant difference $(\mathrm{p}<.07)$ was observed for one of the 96 knowledge dimensions, Training \& Development (IT > IS).

A scattering of significant differences were observed when second discipline was used as an independent variable. The knowledge areas on which significant differences were observed included: Negotiation, Critical Path Method, and IT Hardware. In general, students with business-oriented second disciplines were more likely to perceive each of these knowledge areas as being more important to the practice of PM than students with non-business-oriented second disciplines. Marginally significant $(\mathrm{p}<.10)$ differences were observed on five other knowledge dimensions: Technical Writing, Business Communications, Conflict Resolution, Partnerships, and Database Systems.

\section{Paired Means Comparisons}

As noted previously, a unique identifier (WebCT ID) was captured at each survey administration during Spring Semester 2007 to enable the assessment of changes in the perceived importance of the knowledge dimensions from the beginning to the end of the course.

From the beginning to the end of the Spring Semester 2007 course, an increase in mean importance was observed for 48 of the 96 (50\%) knowledge areas. As illustrated in Table 3, the increases were significant or marginally significant for 17 of the knowledge areas. For several knowledge areas (Function Point Analysis, Critical Path Method, PERT, and Ergonomics), the average student had little or no preexisting knowledge and the statistically significant increases for these areas can be attributed to new learning occurring within the course. The significant increases observed for the other knowledge areas provide stronger evidence that the course has altered student perceptions of their importance.

Declines in mean importance were observed for 41 of the 96 knowledge areas; start and end of course means were identical for seven knowledge areas. Three of the declines were significant or marginally significant (see Table 4).

Table 3: Knowledge Areas Demonstrating Increased Importance at Course End

\begin{tabular}{|l|c|c|c|l|}
\hline Dimension & $\begin{array}{l}\text { Start } \\
\text { Mean }\end{array}$ & $\begin{array}{l}\text { End } \\
\text { Mean }\end{array}$ & $\begin{array}{l}\text { Test } \\
\text { statistic } \\
\text { (t) }\end{array}$ & $\begin{array}{l}\text { Sign. } \\
\text { Level }\end{array}$ \\
\hline Mathematics & 4.07 & 4.45 & -1.886 & .07 \\
\hline Probability & 4.41 & 4.93 & -1.722 & .10 \\
\hline Ethics & 5.07 & 5.38 & -1.877 & .08 \\
\hline $\begin{array}{l}\text { Change } \\
\text { Management }\end{array}$ & 4.24 & 5.62 & -3.803 & .001 \\
\hline $\begin{array}{l}\text { Conflict } \\
\text { Resolution }\end{array}$ & 5.31 & 5.69 & -1.652 & .11 \\
\hline $\begin{array}{l}\text { Function Point } \\
\text { Analysis }\end{array}$ & 1.67 & 5.00 & -7.629 & .001 \\
\hline $\begin{array}{l}\text { ROI } \\
\text { Calculation }\end{array}$ & 4.41 & 5.14 & -2.052 & .06 \\
\hline $\begin{array}{l}\text { Critical Path } \\
\text { Method }\end{array}$ & 2.32 & 5.18 & -5.965 & .001 \\
\hline PERT & 2.34 & 5.14 & -5.590 & .001 \\
\hline $\begin{array}{l}\text { Collaboration } \\
\text { Software }\end{array}$ & 3.71 & 4.79 & -2.546 & .02 \\
\hline CASE Tools & 3.34 & 4.55 & -2.839 & .008 \\
\hline $\begin{array}{l}\text { Incentive } \\
\text { Systems }\end{array}$ & 4.03 & 4.69 & -1.862 & .08 \\
\hline Outsourcing & 4.34 & 5.03 & -2.830 & .009 \\
\hline Procurement & 3.65 & 5.28 & -3.793 & .001 \\
\hline Psychology & 3.69 & 4.52 & -2.571 & .05 \\
\hline Sociology & 3.66 & 4.34 & -2.281 & .03 \\
\hline Ergonomics & 2.97 & 3.97 & -3269 & .003 \\
\hline
\end{tabular}


Table 4: Knowledge Areas Demonstrating Decreased Importance at Course End

\begin{tabular}{|l|c|c|c|c|}
\hline Dimension & $\begin{array}{c}\text { Start } \\
\text { Mean }\end{array}$ & $\begin{array}{c}\text { End } \\
\text { Mean }\end{array}$ & $\begin{array}{c}\text { Test } \\
\text { statistic } \\
\text { (t) }\end{array}$ & $\begin{array}{c}\text { Sign. } \\
\text { Level }\end{array}$ \\
\hline $\begin{array}{l}\text { Database } \\
\text { Systems }\end{array}$ & 4.97 & 4.62 & 2.774 & .01 \\
\hline Programming & 4.28 & 3.97 & 1.797 & .09 \\
\hline $\begin{array}{l}\text { Team } \\
\text { Building }\end{array}$ & 5.72 & 5.41 & 2.531 & .02 \\
\hline
\end{tabular}

The significant declines summarized in Table 4 are not surprising and can be readily explained. As may be observed in Table 2, both Database Systems and Programming are both consistently rated in the bottom half of the knowledge areas in terms of perceived importance at the beginning of the course and the statistically significant decline from course start to course end suggests that the course reinforces their initial perceptions of the overall importance of these areas. The decline for Team Building is more surprising, but as may be observed in Table 1, despite the statistically significant decrease, Team Building remains in the upper third of knowledge areas in perceived importance at the end of the course.

\section{Overall Perceptions of PM Course at End of Semester}

At the end of each semester, PM students completed a second survey designed to capture their overall impressions of the importance of PM knowledge and courses. With one exception, all survey items were rated on a 5 -point Likert scale (1 = strongly disagree; $5=$ strongly agree).

Table 5: Perceived Importance of PM Knowledge and Courses End of Course

\begin{tabular}{|l|c|}
\hline \multicolumn{1}{|c|}{ Survey Item } & \multicolumn{1}{|c|}{$\begin{array}{c}\text { End of } \\
\text { Course } \\
\text { Mean } \\
\text { (n = 72) }\end{array}$} \\
\hline PM knowledge is very important & 4.52 \\
\hline $\begin{array}{l}\text { PM knowledge will have positive } \\
\text { impacts on my career }\end{array}$ & 4.47 \\
\hline $\begin{array}{l}\text { PM knowledge helps in other project- } \\
\text { based courses }\end{array}$ & 4.28 \\
\hline $\begin{array}{l}\text { PM knowledge is necessary for career } \\
\text { success }\end{array}$ & 4.13 \\
\hline PM should be a required course & 4.01 \\
\hline $\begin{array}{l}\text { PM knowledge will have a positive } \\
\text { impact on my personal life }\end{array}$ & 3.75 \\
\hline
\end{tabular}

\begin{tabular}{|l|c|}
\hline $\begin{array}{l}\text { All students should be exposed to PM } \\
\text { techniques in their first year }\end{array}$ & 3.53 \\
\hline $\begin{array}{l}\text { Students in all computing majors } \\
\text { should take a PM course }\end{array}$ & 3.35 \\
\hline $\begin{array}{l}\text { Students in all majors should take a } \\
\text { PM course }\end{array}$ & 3.31 \\
\hline $\begin{array}{l}\text { PM should be offered earlier in the } \\
\text { curriculum }\end{array}$ & 3.28 \\
\hline $\begin{array}{l}\text { The best time to take the PM course is } \\
\text { during the year. }\end{array}$ & 2.82 \\
\hline PM should be an elective course & 2.63 \\
\hline
\end{tabular}

Table 5 summarizes the overall perceptions of PM knowledge and the PM course at the end of the semester. It illustrates strong agreement among the students about the overall importance of PM knowledge and its potential to have positive impacts on their careers. The students also agree that PM should be a required course. Students were more neutral about whether the course should be taken earlier in the curriculum (recall that the majority of the survey respondents were seniors).

\section{Demographic Differences in End of Course Perceptions}

ANOVAs were run to assess whether there were systematic differences for several demographic variables semester, gender, status (junior vs. senior), major, or second discipline. Significant differences (p $<$.05) between Fall Semester 2006 and Spring Semester 2007 students for two items: "All students should take a PM course" (Spring > Fall) and "PM should be offered earlier in the curriculum" (Spring < Fall).

Gender differences were observed on multiple items. As illustrated in Table 6, females generally had more positive attitudes toward PM knowledge and PM courses than males.

The only significant difference between IT and IS majors was observed on the item that asked about the best time to take the PM course. IT majors were more likely to indicate that PM should be taken in year two or three while IS majors were more likely to indicate that it should be taken during year four.

A significant difference for status (junior vs. senior) was also observed for this item. Seniors were more likely to indicate that PM should be taken during year four, while juniors were more likely to report that it should be taken during year three. 
Table 6: Gender Perceived Importance of PM Knowledge \& Courses End of Course

\begin{tabular}{|l|c|c|c|c|}
\hline \multicolumn{1}{|c|}{ Item } & $\begin{array}{c}\text { Male } \\
\text { Mean } \\
\text { (n=58) }\end{array}$ & $\begin{array}{c}\text { Female } \\
\text { Mean } \\
\text { (n=14) }\end{array}$ & $\begin{array}{c}\text { Test } \\
\text { statistic } \\
\text { (F) }\end{array}$ & $\begin{array}{c}\text { Sign. } \\
\text { Level }\end{array}$ \\
\hline $\begin{array}{l}\text { PM } \\
\text { knowledge } \\
\text { is very } \\
\text { important }\end{array}$ & 4.46 & 4.83 & 3.431 & .07 \\
\hline $\begin{array}{l}\text { There } \\
\text { should be a } \\
\text { second PM } \\
\text { course }\end{array}$ & 2.92 & 3.77 & 5.185 & .03 \\
\hline $\begin{array}{l}\text { PM know. } \\
\text { helps in } \\
\text { other } \\
\text { project- } \\
\text { based } \\
\text { courses }\end{array}$ & 5.72 & 5.41 & 2.531 & .02 \\
\hline $\begin{array}{l}\text { PM should } \\
\text { be a } \\
\text { required } \\
\text { course }\end{array}$ & 3.92 & 4.50 & 3.198 & .08 \\
\hline $\begin{array}{l}\text { All students } \\
\text { should be } \\
\text { exposed to } \\
\text { PM } \\
\text { techniques } \\
\text { in first year }\end{array}$ & 3.34 & 4.29 & 4.043 & .06 \\
\hline $\begin{array}{l}\text { Students in } \\
\text { all majors } \\
\text { should take } \\
\text { a PM course }\end{array}$ & 3.14 & 4.08 & 6.895 & .02 \\
\hline $\begin{array}{l}\text { PM should } \\
\text { be offered } \\
\text { earlier in the } \\
\text { curriculum }\end{array}$ & 3.14 & 3.92 & 5.387 & .03 \\
\hline $\begin{array}{l}\text { PM should } \\
\text { be an } \\
\text { elective } \\
\text { course }\end{array}$ & 2.76 & 2.00 & 3.552 & .06 \\
\hline
\end{tabular}

\section{CONCLUSION}

It is clear from the findings that student views of the overall value of project management knowledge are positive. Our findings suggest that student think that project management will help them in their careers. Changes observed in the pre-post perceptions of PM knowledge areas for the Spring Semesters 2007 students suggest that the project Management course is capable of increasing the perceived importance of both quantitative methods (e.g. CPM, PERT, ROI) and "softer" knowledge areas (e.g. psychology, change management, conflict resolution, ethics, ergonomics) to the practice of project management. Our findings also indicate that females may be more likely than males to demonstrate dramatic increases in their overall impressions of the value of project management knowledge.

Our findings indicate that students perceive that there is a wide-range of knowledge dimensions that contribute to effective project management. Indeed, most of the 96 subject areas assessed by our surveys indicated at least "some" importance to effective project management. Our findings also suggest that there is considerable commonality of the knowledge areas that are perceived as being more or of lesser importance to the practice of project management at both the beginning and end of the project management course. The same knowledge areas tend to be clumped near the both the top and bottom (in terms of importance) at both points in time. Because of the relative stability of student perceptions about what is and what is not important, educators may get more mileage out of their courses by focusing on those dimensions that student perceive to be most important.

Because the number of knowledge areas, 96, was rather high for a survey, it is possible that some students did not take the necessary time to consider each carefully. While an extensive number of relevant knowledge areas have been identified by PM researchers (e.g. Brewer, 2005; Brill et al, 2006), we might get a truer reading of student perceptions if this number were reduced by $50 \%$ or more. In addition, it is desirable to add the nine knowledge categories identified in the Project Management Body of Knowledge (PMBOK) to assess the extent to which a university course is capable of altering student perceptions of the relative importance of each of the subject areas stressed by the PMI.

Future studies should further investigate the gender differences observed in this study. Future investigations should also strive to identify whether the pattern of findings similar patterns observed in this investigation for undergraduate students can be replicated for graduate students, especially those with considerable work experience. A direct comparison of the perceptions of graduate and undergraduate students' perceptions of project management knowledge and contributing knowledge area could yield interesting findings. 
As noted by Brewer (2005), enhanced understanding of the skills, competencies, and expertise possessed by effective project managers puts educators in a better position to prepare students for PM careers. Investigations that contribute to honing profile of the effective project manager can assist educators in finding appropriate instructional approaches and learning outcomes to better shape students to match that profile. Such knowledge will also help educators determine the course prerequisites that will best prepare students to excel in the project management course as well as where the PM course is best positioned within the IS curriculum.

\section{REFERENCES}

ABET, 2004, Criteria for Accrediting Computing Programs, Baltimore, MD, Available at http://www.abet.org/criteria_cac.html.

Baker, J., D., Tjosvold, and R. Andrews, 1988, Conflict Approaches of Effective and Ineffective Project Managers: A Field study in a Matrix Organization, Journal of Management Studies, 25(2), 167-178.

Bigelow, D., 2000, What Makes a Good Project Manager?, www.pmsolutions.com/articles/pdfs/pm_skills/good_ pm.pdf

Brewer, J.L., 2005, Project Managers: Can We Make Them or Just Make Them Better?, Proceedings of the 2005 SIGITE Conference on Information Technology Education, October 20-22, 2005, Newark, NJ, pp. 167-172.

Brill, J. M., M. J. Bishop; and Andrew E. Walker, 2006, The Competencies and Characteristics Required of an Effective Project Manager: A WebBased Delphi Study, Educational Technology Research and Development, 54(2), 115-140.

Bourne, L., and D.H.T. Walker, 2004, Advancing Project Management in Learning Organizations, The Learning Organization, 2(3), pp. 226-243.

Capell, J., 2001, Entry Level IS Job Skills: A Survey of Employers, The Journal of Computer Information Systems, 42 (2), pp. 76-82.

Gorgone, J. et. al., 2002, IS 2002 Model Curriculum and Guidelines for Undergraduate Degree Programs in Information Systems.
Milosevic, Dragan, 2003, Project Management Toolbox: tools and Techniques for the Practicing Project Manager, John Wiley \& sons, Inc.

Project Management Institute (PMI), 2000, A Guide to the Project Management Body of Knowledge (PMBOK Guide), Newtown Square, PA: PMI Publishing.

Reif, H., and M. Mitri, 2005, How University Professors Teach Project Management for Information Systems, Communications of the ACM, 48(8), pp. 134-136.

Reif, H. and M. Mitri, 2005, Integration of Project Management Components in Undergraduate Information Systems Curricula, The Journal of Computer Information Systems, 45 (3), pp. 24-31.

Udo, N., and S. Koppensteiner, 2004, What are the Core Competencies of a Successful Project Manager? Proceedings, PMI Global Congress, Prague Hungary, pp. 1-7.

White, B., 2002, Can a Project Manager be a Servant Leader: A Comparative Critique, www.maxwideman.com/guests/servant/characteristic s.htm

Wu, Benjamin, 2005, Characteristics of an Outstanding Business Intelligence Project Manager, www.dmreview.com/article_sub.cfm?articleId=1026 063 